\title{
17
}

\section{The burning question: Claims and counter claims on the origin and extent of buttongrass moorland (blanket moor) in southwest Tasmania during the present glacial-interglacial}

\author{
Mike Macphail \\ Department of Archaeology and Natural History, Research School of Pacific and Asian Studies, Australian \\ National University, Canberra \\ mike.macphail@anu.edu.au
}

\section{Introduction}

Claims and counter claims about the origins of the buttongrass moorland (blanket moor) in southwest Tasmania explicitly or implicitly are founded on the 'ecological drift' concept formulated more than 40 years ago by the late Professor W.D. (Bill) Jackson, at the University of Tasmania. Ecological surveys and modelling experiments have provided much valuable information about the dynamic balance between the plant associations forming buttongrass moorland under present-day climates, soil types and fire regimes. However, thus far, fossil pollen provides the only direct evidence about the origins, geographic extent and long-term directions of change in buttongrass moorland in the prehistoric past. For example, fossil pollen demonstrates that the eponymous species of buttongrass moorland, Gymnoschoenus sphaerocephalus, was present in the Last Glacial vegetation in southern Tasmania during the late Last Glacial period and provides the first compelling evidence that buttongrass moorland may have been continuously present in the Lake Pedder area of southwest Tasmania throughout the Holocene period. This paper compares various models proposed over the past 40 years to account for the development of buttongrass moorland across southwest Tasmania since the Last Glacial period. How well, and on what time scales, the directions and magnitude of changes predicted by the various models are supported by the palaeoecological evidence is important to understanding the climate-vegetation-fire linkages in present-day buttongrass moorland. How useful these models will be in predicting trends under warmer climates is less clear.

Southwest Tasmania shares with, for example, the Lakes District of Britain, the curious distinction of being a cultural landscape that is widely perceived as natural wilderness. In 
both instances, burning by humans is seen as responsible for (and one of the key tools to manage) the mosaic of herbaceous and woody communities that dominate these landscapes - grass and sedge-dominated moorland in the Lakes District and buttongrass moorland in southwest Tasmania. The eponymous, often dominant species of the latter vegetation type, the scleromorphic sedge Gymnoschoenus sphaerocephalus, occurs in perennially damp sites over a range of elevations in mainland southeast Australia and Tasmania. Jarman et al. (1988) split buttongrass moorland in Tasmania into two groups based on floristics and physiographic characteristics - Eastern Moor, which is confined to poorly drained terrain in northern, central and eastern Tasmania, and Blanket Moor, which is confined to the western half of the state where high rainfall has allowed Gymnoschoenus sphaerocephalus to expand beyond the mire niche to cover much of a landscape where rainforest dominance might be expected (see Jackson 1968, 1999). Both types of moorland are dominated by sedges (Cyperaceae) and wire-sedges (Restionaceae), but typically also contain a large proportion of scleromorphic shrubs (Jarman et al. 1988).

Brown (1999) has described buttongrass moorland (blanket moor sensu Jarman et al. 1988) as an oligotrophic 'system' which extends over steep-sided hill slopes and ridges, as well as broad, flat valleys, from sea level to about $1050 \mathrm{~m}$ across much of western and southwestern Tasmania. These moorlands are developed on \pm shallow and highly acidic peat substrates, which overlie typically infertile pre-Carboniferous bedrock or regolith derived from this bedrock. The floristic composition, structure and present-day/short-term dynamics of buttongrass moorland under historical conditions and fire regimes are relatively well researched (references in Brown 1999; Corbett and Balmer 2008; King 2008). In contrast, much less is known about its prehistoric past, including the culturally important question of the origin(s), dynamics, persistence and geographic extent of buttongrass moorland under earlier climatic 'regimes' in the Late Pleistocene (>10 ka BP) and Holocene (10 ka BP to present) in western and southwestern Tasmania.

Reasons for this include a palaeoecological focus on tree-and shrub-dominated communities - in particular, temperate rainforest and highland communities (see Macphail 1979; Markgraf et al. 1986; Colhoun 1996, 2000), as well as an apparent paucity of thick organic deposits within buttongrass moorland that are likely to have escaped periodic truncation by wildfires. Many of the sites pollen-analysed over the past 40 years are either close to or above the presentday upper altitudinal limit of Gymnoschoenus sphaerocephalus, or for those at lower elevations, surrounded by forest, e.g. Brown Marsh on the Central Plateau (Macphail 1979), Lake Johnson on Mount Read in northwestern Tasmania (Anker et al. 2001) and the Upper Ringarooma River valley in northeastern Tasmania (Dodson 2001). Gymnoschoenus pollen counts usually are excluded from published summary pollen diagrams, e.g. for Beattie's Tarn, Lake Dobson and the Tarn Shelf on Mount Field in central southern Tasmania (cf. Macphail 1975a, 1975b, 1979, 1986), or the pollen morphotype is not present or differentiated from other Cyperaceae, e.g. Pulbeena, Mowbray and Broadmeadow Swamps, and Tullabardine Dam in northwestern Tasmania (Colhoun et al. 1982; Colhoun and van de Geer 1986; van de Geer et al. 1986), Newall Creek, King River Valley and Poet's Hill Lake in western Tasmania (van de Geer et al. 1986, 1989, 1991; Colhoun 1992), and Smelter Creek and Governor Bog in southwestern Tasmania (Colhoun et al. 1991, 1992). At sites below about 300 m elevation, Gymnoschoenus may have been conflated with Baumea, which produces morphologically very similar pollen. Possible examples occur in the Lower Gordon River Valley (Harle et al. 1999) and the Louisa Plains/Melaleuca Inlet area of Bathurst Harbour (Thomas 1995; Macphail et al. 1999).

Only eight sites are known to preserve significant $(>2 \%)$ relative abundances of Gymnoschoenus-type pollen: the three Mount Field sites, Ooze Lake in far southern Tasmania (Macphail 1975a, 1986; Macphail and Colhoun 1985; Colhoun 1996), the 'Tarn Shelf' site and Lake Selina in the Tyndall Ranges area of western Tasmania (Colhoun et al. 1999; M.K. Macphail unpubl. data), the Melaleuca Inlet site (Thomas 1995) and a pond near Lake 
Pedder in central southwest Tasmania (Fletcher and Thomas 2007a). The last site is unique at present in that Gymnoschoenus-type pollen is more or less frequent throughout the Holocene, assuming continuous deposition at the core site.

This paper discusses fossil pollen evidence for buttongrass moorland in western Tasmania before European settlement, in particular the claim by Fletcher and Thomas (2007a) that the Lake Pedder Pond sequence is evidence that buttongrass moorland has been continuously present in the lowlands of southwest Tasmania since the Last Glacial period. Fossil pollen data from other sites in western Tasmania, including sites from within buttongrass moorland, have been reviewed by Colhoun (1996). The names given to the various ecological models are those used by their authors or informal names coined for the purpose of this paper.

\section{Claims and counter claims}

Ecological and pollen analytical studies carried out over the past 40 years have resulted in five models that implicitly or explicitly have (or can be) used to 'explain' the presence of about one million hectares of buttongrass moorland in high rainfall regions capable of supporting temperate rainforest or (subalpine zone) rainforest scrub. All models assume that buttongrass moorland and other sclerophyll-dominated associations in western Tasmania are 'fire-promoting and fire-requiring' vegetation types, resulting from repeated firing of the vegetation by the Tasmanian Aborigines in the prehistoric past. All are based to a lesser or greater degree on the seminal 'ecological-drift' model published by late Professor W.D. (Bill) Jackson (1968, revised 1999) to account for complex relationships between fire-sensitive rainforest and fire-tolerant sclerophyll associations observed in high-rainfall areas of western Tasmania (Figure 1).Given the long history of logging old-growth forests and concomitant debate on the regeneration of commercial eucalypt forests, it is not surprising that earlier research such as that by Jackson (1968), Mount (1979) and Macphail (1980) focused on forest management practices rather than the history of buttongrass moorland per se.

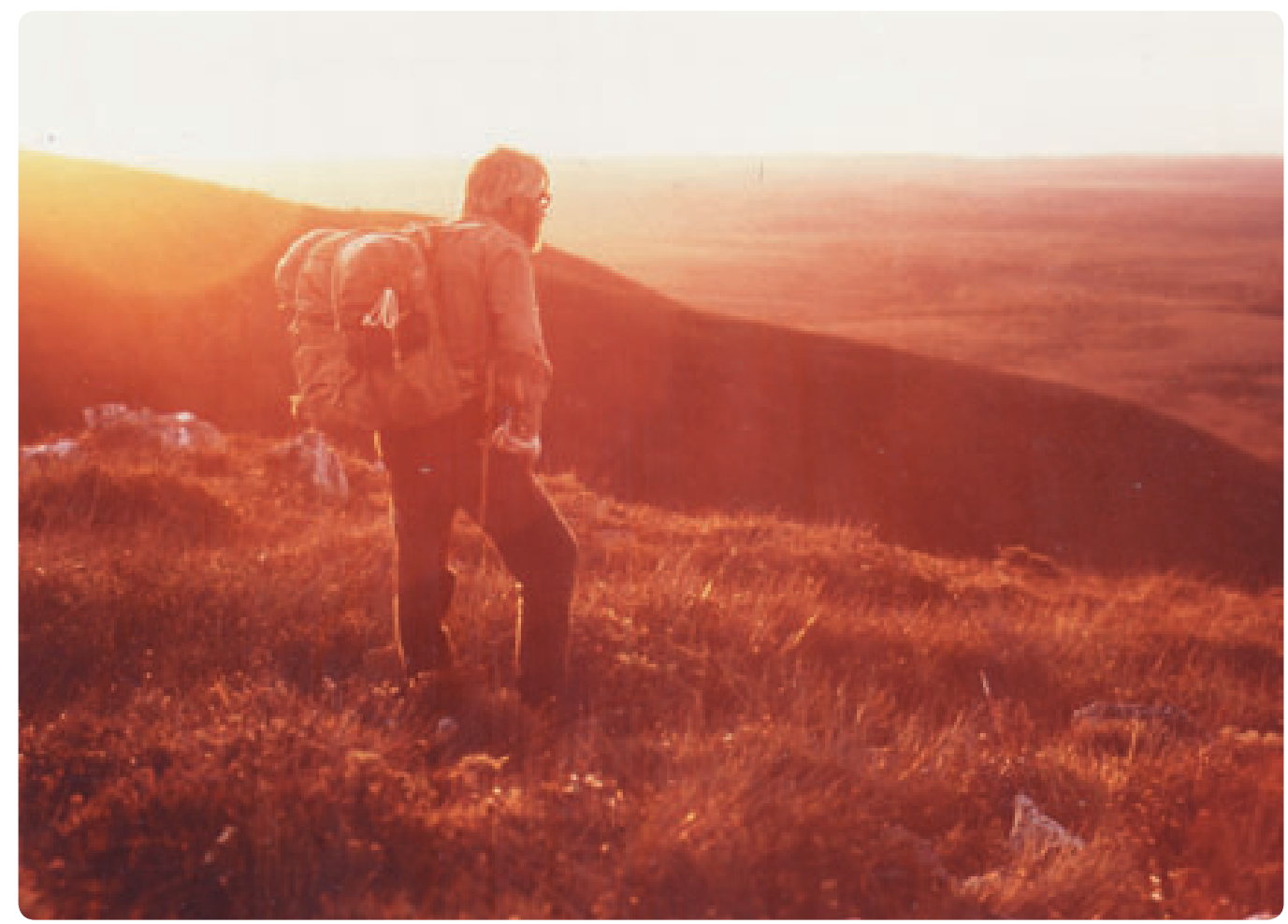

Figure 1. Professor Bill Jackson (1975) on the summit of Mount Hazleton, looking across lowland buttongrass moorland below the Norfolk Range, western Tasmania. Photograph by M.K. Macphail 


\section{The 'ecologic drift' hypothesis of Jackson (1968)}

Jackson (1968) has proposed that buttongrass moorland is a fire-disclimax plant formation that has been able to expand beyond its natural (mire) limits on to steeper terrain, due to a combination of uniformly wet climates and frequent wildfires in the (unspecified) prehistoric past. Critical assumptions are that: (1) ignition sources primarily were Aborigines living on the coast or migrating into the interior along defined trails, not lightning strikes; (2) the arrival of fires in any (inland) locality occurs randomly in time; (3) the vegetation follows a relatively clear successional pattern from sedgeland to Nothofagus temperate rainforest via intermediate sclerophyll scrub and wet sclerophyll forest seres; and (4) the probability that the vegetation occupying a site will burn is related to its composition. In general, the higher the sclerophyll component, the greater the fire-risk status of the community - i.e. the probability of fire occurring is greater in the earlier, sclerophyll-dominated communities, than in subsequent seral rainforest communities.

The model predicts that as the (chance) interval between successive fires increases, the more likely it is that fire-sensitive vegetation types (chiefly mixed forest and temperate rainforest) will succeed sclerophyll-dominated vegetation types. The reverse situation, characterised by high fire frequencies and an associated loss of soil nutrients, leads to highly inflammable communities, in particular buttongrass moorland. Seral communities are predicted to 'drift' between the two end states (Nothofagus temperate rainforest, Gymnoschoenus buttongrass moorland) according to the small chance occurrences of very long or very short intervals between fires.

\section{The 'stable fire cycle' model of Mount (1979)}

Mount (1979) used a paper discussing short-term processes controlling regeneration in presentday Tasmanian forests (fire, drought, wind-throw, flood and faunal predation) to challenge the 'ecologic drift' model, in particular Jackson's (1968) arrangement of observations made at different locations into the one temporal sequence. Instead, fire was seen as the most important of a spectrum of 'barrier-removing' agencies that prevent forest regeneration. Key assumptions differ from those of Jackson (1968) in that: (1) natural ignition sources are believed to have maintained a constant presence of fire in Tasmania, including in high rainfall areas remote from habitation sites; (2) the probability of a fire occurring depends on the total fuel load, not just the sclerophyll component as proposed by Jackson (1968); and (3) all vegetation types are intrinsically flammable but burning will not occur until sufficient fuel loads have accumulated. The low fuel period (LFP) during which a community cannot catch fire was estimated to vary from about six months in Gymnoschoenus communities to about 80 years in Nothofagus temperate rainforest. Mount's (1979) observation that burning lichens can cause 'spot' fires in rainforest is supported by a subsequent study of the impact of fire in a droughtimpacted rainforest (Hill 1982).

Because frequent fires in communities with short LFPs will only occasionally ignite fires in adjacent vegetation types with long LFPs, boundaries between the major vegetation types are predicted to remain geographically stable over time. Accordingly, Mount (1979) proposed that the mosaic of forest and non-forest communities in western Tasmania was the result of stable fire cycles, rather than the individual associations representing different seral stages towards and away from two \pm stable end-member formations (temperate rainforest and buttongrass moorland). 


\section{The 'climate reinforcement' model of Macphail (1980)}

Macphail (1975a, 1979, 1980, 1986) proposed that postglacial climate change, not fire or humans, is the primary determinant of long-term trends in the (forest) vegetation, although this control may have been indirect via long-term 'feed-back' relationships between climate and soil fertility, and climate and fire frequency, as proposed by Jackson (1968).

This model is based on fossil pollen sequences preserved in 10 glacial tarns and peat swamps aligned along altitudinal and east-to-west gradients across southern Tasmania and used to reconstruct the history of the regional vegetation and climates in southern Tasmania during the Postglacial period, c. $13 \mathrm{ka} \mathrm{BP}$ to present. Despite major variation at the local (individual site) scale, the study indicated that the postglacial forest vegetation in southern Tasmania could be divided into early and late temperate developmental phases, preceded by a pre-temperate phase during which the vegetation at lower elevations was subalpine to alpine in character. Radiocarbon dates show the early temperate phase began about $10 \mathrm{ka} \mathrm{BP}$ and ended between 6 and 7 ka BP (late-early to middle Holocene). During this interval, Nothofagus temperate rainforest associations expanded out of Late Glacial refugia in western Tasmania and on mountains in the centre and south, while Eucalyptus sclerophyll forests expanded on the Central Plateau and in eastern Tasmania (cf. Kirkpatrick and Fowler 1998). The late temperate phase began about $6 \mathrm{ka}$ BP (middle Holocene). During this interval, many forest and non-forest communities across a range of elevations became more open in structure.

Central to Macphail's (1980) model is the hypothesis that the overall impact of wildfires has varied during the Postglacial period depending on whether the ecological effects of climate change have curtailed (opposed) or reinforced (complemented) the fire-dictated 'drift' away from rainforest. Thus, increasing warm and wet conditions during the early Holocene are seen as having allowed temperate rainforest communities to expand at higher elevations irrespective of (anthropogenic) fire pressure, while increasingly variable (cooler, more drought-prone) conditions during the middle and late Holocene resulted in the regional expansion of sclerophyll vegetation types. This climate-forced reversion (revertance) to more open vegetation types during the late Holocene is diachronous in that the trend occurred earlier and is most apparent in the fossil pollen record in central and southeast Tasmania, less so in the perhumid west and far south. For example, fossil pollen data show that temperate rainforest communities have dominated the mid slopes of Frenchmans Cap (Lake Vera glacial trough valley) throughout the Holocene, while infilled glacial tarns at higher elevations on the Denison (Upper Wurawina cirque) and Tyndall Ranges (Tarn Shelf) have supported rainforest scrub over much the same period (Macphail 1986).

At the time of publication, the only lowland site for which fossil pollen data were available were rain-shadowed sites that were (and are) too dry to support Gymnoschoenus, viz. Lake Tiberias in the Midlands and thin organic deposits in coastal southeast Tasmania. Nevertheless, if the 'climate reinforcement' concept is extrapolated to the western lowlands, the model predicts that buttongrass moorland will have (1) been least extensive during the early Holocene, (2) begun expanding during the middle Holocene and (3) attained its presentday distribution during the late Holocene as the direct and indirect impacts of Aboriginal fires were reinforced by a higher frequency of short-term 'drought events'.

\section{The 'Iversen glacial-interglacial cycle' model of Colhoun (1996)}

Colhoun (1996) accepted that the change from glacial to interglacial climates directed vegetation successions in western Tasmania, but challenged Macphail's $(1979,1980)$ thesis that climatic change per se underlies the late-Holocene revertance. Instead, the non-synchronous nature of plant succession recorded at many sites is suggested to be conclusive evidence that 
biological and physical variables other than climate change were more important. The former (biological factors) include different rates of migration away from Last Glacial refugia; the latter (physical factors) include edaphic phenomena, such as the impact of anthropogenic fires on soil depth, drainage and fertility.

The theoretical basis for these conclusions is the 'glacial-interglacial' model of Iversen (1958). This model, which is widely used in the interpretation of European, British and eastern North American pollen sequences, subdivides glacial-interglacial vegetation successions into four stages, each of which is associated with different stages in the soil maturation-degradation cycle. These are: (1) the Cryocratic Stage, during which frost disturbance prevents herbaceous plant associations (tundra) from completely covering the ground surface; (2) the Protocratic Stage, during which tundra is replaced by grasslands and woodlands growing on unleached calcareous soils; (3) the Mesocratic Stage, during which 'climax' forests occupy sites with deep, slightly acid but relatively fertile soils; and (4) the Telocratic (or Oligocratic) Stage, during which the climax forests revert to lower, more open vegetation types as soils become less fertile, and more poorly drained and acidic due to leaching under colder (and wetter?) climates. In western Tasmania, the Cryocratic and Protocratic Stages encompass the replacement of fell-field and herbfield communities by subalpine-alpine heath and scrub during the latest Pleistocene; the Mesocratic Stage is seen as culminating in the expansion of Nothofagus cool temperate rainforest 'throughout' (Colhoun 1996:565) the lowlands sometime before the middle Holocene, while the Telocratic/Oligocratic Stage encompasses the replacement of floristically simple/closed forest types by floristically more complex/open shrub and herbaceous communities, including heath/moorland, during the late Holocene.

The sequence of communities corresponds closely to those observed by Macphail (1979, 1980), but the Holocene reversion towards more lower, open vegetation types is attributed to cultural and environmental factors other than climate, in particular increased burning by Aborigines, soil impoverishment and local sedimentation effects. Colhoun (1996:578) notes that 'the development of [rainforest] vegetation must locally have been retarded by variations in nutrient status of soil types and drainage of the landscape as influenced by topography'. However, he does not argue that the late Holocene forest 'retreat' reflects the inability of tree species to colonise poorly drained/highly acidic blanket peats once these have developed, even though this is seen as a major factor forcing revertance in the Iversen (1958) model (cf. Figures 2 and 3 in Colhoun 1996).

\section{The 'Last Glacial inheritance' hypothesis of Fletcher and Thomas (2007a)}

Fletcher and Thomas (2007a) have used fossil pollen preserved in a pond at $312 \mathrm{~m}$ elevation near Lake Pedder (hereafter LPP site), supported by published palynological data from other sites within moorland, to challenge two of Colhoun's (1996) key predictions - that rainforest dominated the landscape of western Tasmania during the mid Holocene, and nutrient-leaching, not climate change, was responsible for the decline in rainforest during the late Holocene. Instead, they argue that (1) fire-promoted buttongrass moorland has dominated the landscape since the Last Glacial period, if not earlier, and (2) the mosaic of vegetation types in western Tasmania has remained relatively stable in extent throughout the Holocene whether or not cooler/drier conditions have resulted in increasingly open forest types and an expansion of subalpine communities on adjacent mountains over the past 6000 to 7000 years.

Like Macphail's (1980) hypothesis, the model is underpinned by a detailed analysis of the modern pollen rain and, with some reservations (see Fletcher and Thomas 2007a:670), assumes that the LPP site preserves a mostly continuous record of the local and non-local to regional vegetation during the Holocene. Key observations are: (1) Gymnoschoenus has been continuously present since at least $10.3 \mathrm{ka} \mathrm{BP}$; (2) objective comparison of the fossil and 
modern pollen data (and high concentrations of carbonised particles) confirms that buttongrass moorland has surrounded the site over this period; (3) relatively low pollen percentages for forest taxa show that at no time has rainforest or any other forest type been established around the site or dominated the regional lowland vegetation.

Fletcher and Thomas (2007a:674) concur with previous workers (references in Brown 1999) that the arrival of Aborigines in southwest Tasmania 'provided an ignition source to a perennially wet landscape in which natural ignition sources are rare', and therefore conclude that the absence of forests in inland southwest Tasmania is due to the continuing influence of (Aboriginal) people in the interior of southwest Tasmania. Accordingly, the model challenges archaeological data that imply the spread of rainforest communities during the Holocene was responsible for displacing Aboriginal occupation sites on to the coast (cf. Kiernan et al. 1983; Cosgrove et al. 1990; Thomas 1993; Cosgrove 1999).

\section{Testing the models}

All the models discussed above make predictions about the origin and/or geographic extent of rainforest vs. buttongrass moorland that potentially can be tested using tightly AMS-dated palynological evidence (including carbonised particle evidence).

One such test was undertaken by Macphail (1980), who used fossil pollen evidence to compare the 'ecological drift' and 'stable fire cycle' models of Jackson (1968) and Mount (1979), respectively. Macphail (1980) proposed that the critical difference between these two models is that the 'stable fire cycle' model predicts that the boundaries between the major communities in western Tasmania would be 'fixed' in space during the Holocene, whereas the 'ecological drift' model predicts the position of the vegetation boundaries would vary over the same period. The 1980 comparison indicated that the regeneration processes identified by Mount (1979) are important in forest regeneration in high rainfall areas, but each operates on a relatively small scale at any point in time. Conversely, the long-term regional successions recorded by fossil pollen match trends predicted by Jackson (1968). Nonetheless, Macphail (1980) recognised that the very low probability that an area of buttongrass moorland would escape burning for a sufficiently long period for forest species to be established (see Figure 3 in Jackson 1968) gave buttongrass moorland the long-term stability envisaged by Mount (1979) and the fire-disclimax status proposed by Jackson (1968).

In contrast, the 'Last Glacial inheritance' model of Fletcher and Thomas (2007a) explicitly uses fossil pollen and charcoal evidence to infer the regional extent as well as the origins of buttongrass moorland in lowland southwest Tasmania since the Last Glacial. For this reason, a number of questions needs answering before their conclusions, which are based primarily on one site, can be extrapolated to the southwest in general. These include consideration of the strengths and weakness of fossil pollen data in general, as well as specific questions regarding the LPP site. Examples are: (1) Does the LPP site preserve a \pm continuous record of the Holocene vegetation? (2) Is the presence of Gymnoschoenus pollen essential evidence that buttongrass moorland formed the regional lowland vegetation surrounding the LPP site during the Holocene? (3) What is the evidence for buttongrass moorland in southwest Tasmania during the late Pleistocene? (4) Are there alternative explanations for the low relative abundance of forest tree pollen in the Lake Pedder pond sequence? A related but more general question is whether fossil pollen data can be used to distinguish between climate-forced revertance and reversion forced by other cultural and environmental factors, such as the impact of indigenous fire on rates of accumulation of organic matter (peat), and the loss of soil fertility due to the combined effects of burning and leaching in high rainfall areas.

Without answers to these questions, it is premature to use fossil pollen and carbonised particle data to infer buttongrass moorland has dominated the southwest lowlands during 
the present glacial-interglacial cycle. With answers, it may be possible to use the fossil pollen and charcoal evidence from a network of strategically located sites to predict the longer-term consequences of management strategies centred on planned fires. As elsewhere, the precision with which the palynological data can be used to reconstruct past climate-vegetation-fire linkages is limited by factors intrinsic to the technique, as well as the characteristics of the individual sites.

\section{Fossil pollen evidence - constraints and opportunities}

Fortunately, as regards the impact of Aboriginal burning practices, southwest Tasmania is a special case in Australia in having floristically simple major vegetation types, which are dominated often by species that produce morphologically distinctive pollen or spores (cf. Macphail 1979; Colhoun 1996; Tables 13.2, 7.1, 10.4 in Brown 1999; Jarman et al. 1999; and Wells and Hickey 1999).

Nevertheless, interpretation of all fossil sequences is constrained by the following factors: (1) Different plant taxa vary greatly in the amount of pollen or spores (and charcoal) they produce and the distance these are dispersed into the surrounding landscape. (2) Most pollen types can be identified only to family or genus, except under unusually favourable circumstances. (3) Some important canopy tree species can survive as shrubs and produce pollen under unfavourable conditions. For these reasons, all fossil pollen assemblages are a partial record of past floras, with some indication of the relative abundance of the parent plants, and the plant community structure has to be deduced by analogy - e.g. when a fossil flora appears to match the composition of an extant community. Using pollen and spores to reconstruct past environments involves additional assumptions (see Birks and Birks 1980). In many instances, conclusions are based on only a fraction of the fossil data, in some cases the presence of one or two 'indicator' species only. Charcoal preserves well in waterlogged sediments but, unlike pollen, is produced in large amounts only at irregular intervals and also is subject to breakdown from larger (macrocharcoal) to smaller-sized (microcharcoal) particles during release, transport and deposition(Figure 2). Accordingly, the relative abundance of charcoal particles provides evidence of local fire activity, but trends are difficult to interpret in regional terms unless calibrated by modern taphonomic studies complemented by standardised charcoal data from a network of sites (see Patterson et al. 1987; Whitlock and Larsen 2001; Conedara et al. 2009).

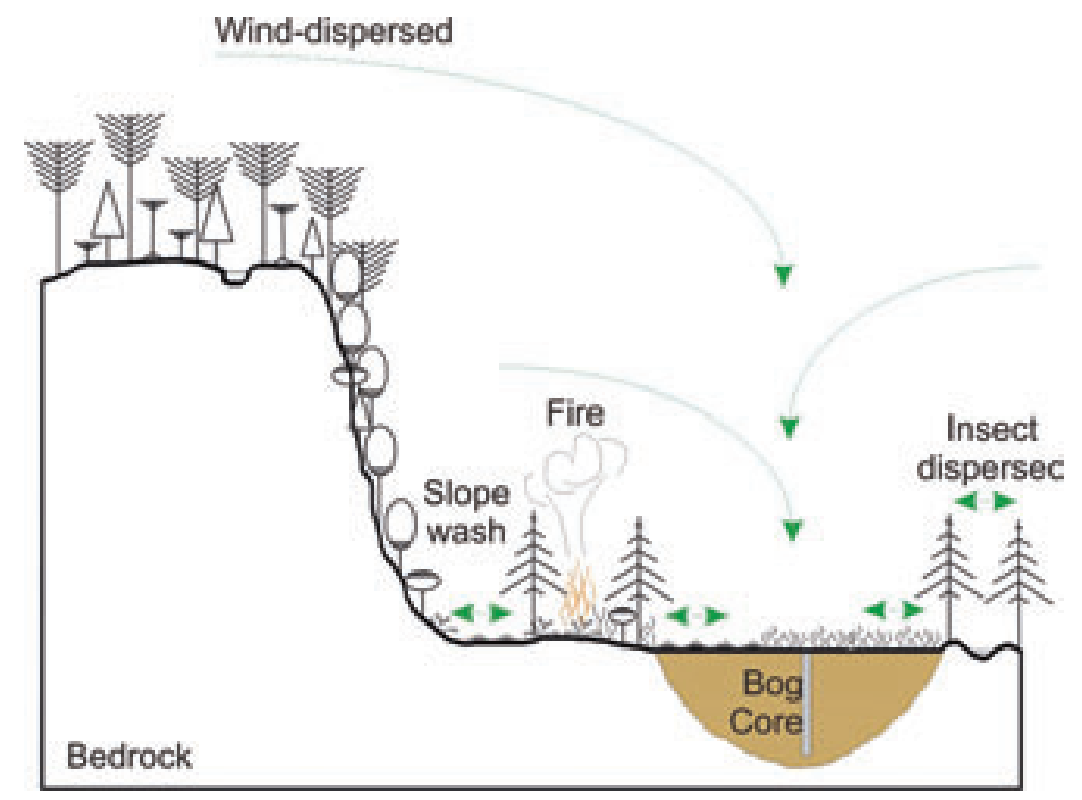

Figure 2. Transport and deposition of pollen and charcoal particles (after Condera et al. 2009) 


\section{Does the LPP site pollen sequence represent all or only part of the Holocene?}

Macphail and Hope (1985) and more recently Macphail et al. (1999) have demonstrated that many mire sequences include one or more disconformity surfaces that represent all or part of mid-Holocene time. The missing section may be due to wildfires burning into the organic deposits, or simply due to local conditions during this period not supporting the longer-term accumulation of organic matter.

Fletcher and Thomas (2007a:670) note that high concentrations of carbonised particles indicate that fires were a significant feature of the (local) environment at the LPP site throughout the Holocene, and a hiatus resulting from burning of a 'dry pond surface' after about $6.5 \mathrm{ka} \mathrm{BP}$ is 'possible'. This can only be tested by additional radiocarbon dates. If the 'spike' in Lagarostrobos pollen at $30 \mathrm{~cm}$ in the LPP core correlates with similar spikes in the relative abundance of this well-dispersed pollen type elsewhere in southern Tasmania, then this sample accumulated sometime between about 4.5 and 3.5 ka BP (see Figures 13-16 and 19 in Macphail 1979). Underlying sediments at c. $37 \mathrm{~cm}$ are dated to about $6.7 \mathrm{ka} \mathrm{BP}$ and the combined data are circumstantial evidence that all or part of the middle Holocene is missing in the LPP core. For these reasons, Fletcher and Thomas's (2007a) conclusions regarding the vegetation developments during the late middle Holocene are considered to be premature.

\section{Is the presence of Gymnoschoenus pollen essential evidence that buttongrass moorland formed the regional lowland vegetation surrounding the LPP site during the Holocene?} Given the prominence of Gymnoschoenus in present-day Blanket Moorland, determining whether this vegetation type formed the regional vegetation in lowland southwest Tasmania would appear to depend on whether Gymnoschoenus pollen can be distinguished from other Cyperaceae pollen at the LPP site, and whether these records represent regional as well as local buttongrass moorland.

Many of the shrubs and herbs found in buttongrass moorland cannot be distinguished to species level using fossil pollen, and at the generic level occur in other vegetation types. For these reasons, fossil Gymnoschoenus pollen are assumed to be diagnostic of buttongrass moorland. Modern reference material indicates Gymnoschoenus pollen can easily be confused with pollen of the unrelated sedge genus Baumea, three species of which occur in buttongrass moorland (Table 13.3 in Brown 1999), although none appear to range above elevations of about $500 \mathrm{~m}$ (Curtis and Morris 1994). B. tetragona is recorded in buttongrass moorland at McPartlan Pass (320-330 m elevation) at the northern end of Lake Pedder (G.J. Jordan pers comm.), although it is uncertain whether this or other Baumea species also occur at the LPP site (312 m elevation). The same caveat applies to Macphail et al.'s (1999) study of peat mounds in buttongrass moorland near sea level at Port Davey in southern Tasmania. Conversely, Gymnoschoenus-type pollen preserved in mires located above about $500 \mathrm{~m}$ elevation is likely to represent Gymnoschoenus sphaerocephalus.

Pollen samples from pollen traps, moss polsters and surface muds in western Tasmania show that Gymnoschoenus sphaerocephalus is poorly represented by pollen and, not surprisingly, Gymnoschoenus pollen was absent in a number of modern samples collected in buttongrass moorland (Table 1 and Figure 3 in Fletcher and Thomas 2007a). Nevertheless, the pollen type is found in trace amounts in surface samples and pollen traps from the lowlands (below $160 \mathrm{~m}$ elevation) into the alpine zone (above $1200 \mathrm{~m}$ elevation) on Mount Field, as well as in pollen trap and surface samples from the Henty River Plains below the Tyndall Ranges, Yeates Lagoon on the Western Tiers, and Pine Lake and Lake Augusta on the eastern side of the Central Plateau (Macphail 1975a). The maximum value recorded by Macphail (1975a) was $1 \%$, in a mud sample collected in the upper subalpine zone on Mount Field. Since buttongrass moorland occurs in the vicinity of or (as in the alpine zone on Mount Field) below the trap or sample sites, the empirical evidence supports Fletcher and Thomas's (2007a) claim that 
even low relative abundances of fossil Gymnoschoenus pollen are, in fact, reliable evidence for buttongrass moorland in the vicinity of the core site.

Whether 'common' occurrences of fossil Gymnoschoenus pollen at the LPP site represent more than locally growing hummocks is less clear. Fletcher and Thomas (2007a) therefore have relied on objective correlation ('finger-printing') techniques to show that fossil pollen assemblages preserved at the LPP site fall within the buttongrass moorland (rather than the alternative rainforest and alpine groups), and cite high charcoal particle values as supporting evidence. In a subsequent paper, they demonstrate that the same objective technique applied to the uppermost samples from Poets Hill Lake, Governor Bog, Smelter Creek and Lake Selina successfully predicted the presence of moorland at these four sites despite the (apparent) absence or non-recognition of Gymnoschoenus pollen (Fletcher and Thomas 2007b). The logical corollary is that the presence of Gymnoschoenus is helpful but not essential to the recognition of buttongrass moorland in the fossil pollen record, although it should be noted that the objective criterion distinguishing buttongrass moorland from other regional vegetation types is essentially negative viz. the paucity of rainforest taxa compared with values recorded at high elevation sites (see below).

\section{Was Gymnoschoenus-dominated moorland present in southwest Tasmania during the late Glacial?}

The oldest known macrofossil evidence of Gymnoschoenus sphaerocephalus in southern Tasmania is remains dated at about $3.5 \mathrm{ka} \mathrm{BP}$ in the Broad River Valley, Mount Field (Caine 1967). Relative abundances of Gymnoschoenus-type pollen (7\%) at the base of the LLP core are strong (albeit circumstantial) evidence that buttongrass moorland was present in the region during the Last Glacial (see Figure 6 in Fletcher and Thomas 2007a), and there is little doubt that Gymnoschoenus, if not buttongrass moorland, was a persistent element in southern Tasmania, based on trace numbers of its fossil pollen in all sites analysed by M.K. Macphail except for Lake Tiberias (Midlands) and Brown Marsh (eastern Central Plateau) (Macphail 1975a, 1979, 1984, 1986; Macphail and Jackson 1978; Macphail and Colhoun 1985).

Whether the LPP and other palynostratigraphic data support Fletcher and Thomas's (2007a) suggestion that buttongrass moorland extended beyond the mire niche to dominate lowland southwest Tasmania during the late Glacial is debatable for palaeoclimatic reasons. For example, much of southeast Australia and Tasmania was subject to 'cold/arid' conditions during the Last Glacial Maximum (cf. Macphail 1975b; Hope 1994; Colhoun 2000). Nonetheless, at least three upper subalpine sites on Mount Field (Beatties Tarn, Lake Dobson, Tarn Shelf) and two sites in far southern Tasmania (Adamsons Peak, Ooze Lake) preserve frequent (2-5\%) numbers of Gymnoschoenus-type pollen in radiocarbon-dated sections that are substantially older than 9 ka BP (Macphail 1975a, unpubl. records). In most instances, the sections are dated to about $11.5 \mathrm{ka} \mathrm{BP}$, with the Ooze Lake sequence extending the record of Gymnoschoenus back to 14-17 ka BP (cf. Macphail and Colhoun 1985; Colhoun 1996).

These and other high-elevation records are distinctly anomalous compared with the Holocene records, since the pollen types appear to be poorly dispersed (see Fletcher and Thomas 2007b) and the sites were (and still are) at or above the modern upper altitudinal limits of Gymnoschoenus. Possible explanations are (1) postglacial warming has caused the extinction of an 'alpine' ecotype, or, preferred, (2) the pollen type has been transported upslope by wind from populations growing in mires at lower elevations. If the latter is correct, then the fact that Gymnoschoenus pollen is only sporadically recorded in Holocene assemblages at higher elevations is likely to be due to two related factors. The first is the marked increase in the local pollen influx at about the Pleistocene-Holocene boundary (due to colonisation of the upper subalpine-alpine zone by woody taxa). The second, which is supported by modern pollen trap and surface sample data, is the saturation of the upper subalpine-alpine assemblages by pollen 
and spores transported upslope from plants that produce/disperse pollen or spores in very large numbers (well-represented taxa) in the montane and lowland forests during the Holocene.

\section{Is the low representation of forest during the Holocene at the LLP site apparent or real?}

The relationship between proximity/abundance of a vegetation type and its representation in the fossil pollen record is complex (Figure 2) and depends not only on the pollen production/ dispersal characteristics of the dominant taxa, but also on the depositional environment and the way the fossil pollen data are presented.

For example, except for sequences with closely spaced radiocarbon dates (which allow numbers of pollen grains to be estimated in absolute terms: see Birks and Birks 1980), fossil pollen counts are expressed as percentages of a pollen sum comprising all or part of the total pollen counts for that sample (relative pollen counts). These percentage data are subject to a strong inverse correlation effect in that an increase in the relative abundance of one pollen type artefactually decreases the relative value of all other pollen types included in the pollen sum. Accordingly, it can be difficult to determine whether low to moderate values are evidence that the parent plants were present but uncommon at/around a site, or were common but growing at a distance from that site. The problem is aggravated by including pollen of under-represented taxa to make up statistically significant ( $>250$ count) pollen sums. For this reason, wetland taxa are usually excluded from the pollen sum. If pollen counts are sufficiently high $(>>250$ counts), relative abundance values can be calculated using pollen sums that comprise only wellrepresented taxa (e.g. Macphail 1975a, 1979; van de Geer et al. 1991; and Colhoun 1996.)

Exclusion of under-represented taxa from the pollen sum minimises the impact that variation in local abundance of the parent plants has on the relative-abundance data for other plants in the pollen source area, especially well-represented taxa growing at some distance from the site (extra-local and regional vegetation). However, in all pond and mire sites, it is difficult, if not impossible, to compensate for effects arising from changes in the pollen deposition regime due to colonisation of the mire surface by plants. This phenomenon, which is analogous to the Neves Effect in large lakes (see Traverse 1988), means that pollen assemblages deposited on the surface of mires (or close to the shoreline of small ponds) usually are dominated by pollen sourced from the local vegetation (high local pollen influx), while assemblages accumulating on unvegetated mire surfaces or in open water in larger lakes will include a higher proportion of pollen and spores derived from well-represented taxa in the extra-local and regional vegetation (non-local pollen influx).

Based on these criteria, pollen assemblages accumulating in the LPP site will have been dominated by locally sourced pollen, except possibly during the earliest Holocene, when Isoetes (presumed to be I. gunnii), Myriophyllum and Astelia indicate the site was an alpine-subalpine bog with pools of free-standing water. Subsequently, pollen and spores of these obligate aquatic herbs disappear from the pollen record, and it seems probable that local water tables were at or below the sediment surface, allowing Restionaceae and probably Gymnoschoenus to colonise organic soils accumulating within the depression. Whether sclerophyll shrubs (Bauera, Epacridaceae, Myrtaceae and? Asteraceae) were able to colonise the mire surface is less clear. If this was the case, then it is plausible that some (much?) of the pollen dispersed from distant stands of Nothofagus cool, temperate rainforest and other forest types was filtered out by locally growing shrubs or strongly diluted by the pollen shed by locally growing plants.

If correct, then it follows that the regional abundance of trees such as Nothofagus cunninghamii has been underestimated for the LPP site. Because the pollen sum adopted by Fletcher and Thomas (2007a) includes sclerophyll shrubs and herbs, it is difficult to compare the relative-abundance values with those recorded in highland sites analysed by M.K. Macphail and E.A. Colhoun (see Colhoun 1996). Given palaeobotanical evidence that Nothofagus populations expanded beyond their present range in the lower Derwent Valley and eastern 
Midlands in southeast Tasmania during the early Holocene (Colhoun and Moon 1984; Harle et al. 1993), it would be surprising if forest did not extend on to lowland areas in southwest Tasmania about the same time.

\section{Can fossil pollen data be used to distinguish between climate- and non-climate forcing of late Holocene revertance/reversion in southwest Tasmania?}

Palaeobotanical evidence has been widely used to infer climate change in western Tasmania, but attempts to use fossil pollen evidence to separate out the effects of fire pressure and soil deterioration from climate (cf. Colhoun 1996) seem to be futile except at sites where independent evidence allows one or both variables to be excluded. Such ideal sites may occur within rainforest stands (see Macphail 1984; Dodson et al. 1998), but this is improbable in buttongrass moorland. Reasons include: (1) it is highly likely that mean and seasonal rainfall and air temperatures greatly exceeded the minimum requirements for buttongrass (and most forest species) throughout the late Holocene; (2) general agreement exists that the regeneration of Gymnoschoenus and other moorland species depends on frequent burning; and (3) modern observations indicate that, at the community level, rainforest and buttongrass are not constrained by regolith geology, although floristic diversity and growth rates (and presumed competitive abilities) of individual taxa will vary with different substrates. For example, Nothofagus temperate rainforests are able to thrive on Precambrian quartzites and other highly infertile rock types as well as on more fertile lithologies and organic substrates (see Read 1999). Nutrient cycling in buttongrass moorland has not been studied in detail. However, the efficiency of many moorland plants in recycling phosphorus and potassium from moribund foliage (Bowman et al. 1986) is circumstantial evidence that buttongrass moorland also may be \pm independent of edaphic constraints in high rainfall regions. One probable reason is the continuous input of 'cyclic salts' from rainwater, as was proposed for rainforest communities by W.D. Jackson in the early 1970s (Jackson 1977; Brown 1999).

\section{Geographically stable boundaries - a critical test for inferring past fire frequency?}

Local-scale evidence continues to support Jackson's (1968) thesis that buttongrass moorland is an intrinsically unstable ecosystem whose boundaries with other communities has and will continue to shift due to changes in fire pressure (whether climate-forced and/or cultural). For example, Phyllocladus and other rainforest species were observed to colonise lignotuber 'rafts' around (now submerged) Lake Edgar near Lake Pedder (Macphail and Shepherd 1973) and moribund Gymnoschoenus hummocks occur within wet scrub near Mount Anne and elsewhere in southwest Tasmania (G.J. Jordan and M.K. Macphail pers obs.). Moreover, a comparison of the Colhoun et al.'s (1999) Lake Selina sequence (where Gymnoschoenus pollen appears relatively late in the poorly dated postglacial section) and the LPP site (where Gymnoschoenus pollen is frequent throughout the Holocene) imply the development of buttongrass moorland may have been as diachronous as has been observed for other vegetation types in western Tasmania.

Nevertheless, conclusions reached by Fletcher and Thomas (2007a) regarding buttongrass moorland in southwest Tasmania are remarkably similar to Mount's (1979) prediction that community boundaries are 'fixed in space' due to stable fire cycles in time - the more so if Mount's (1979) pervasive 'natural' ignition sources are replaced by 'cultural' ignition sources. As recognised by Fletcher and Thomas (2007a), their evidence also challenges Kiernan et al.'s (1983) conclusion that the early Holocene expansion of rainforest was responsible for the retreat of Aboriginal communities on to the west coast. Even though there is no archaeological evidence that Aboriginal communities were living away from the coast in southwest Tasmania during the Holocene, such evidence may yet be found. For example, Aboriginal flake tools have been found at Lake Pedder (J. Marsden-Smedley pers comm.) and Macphail et al. 
(1975:100) recorded a stone scraper buried under thick sclerophyll scrub growing on Tertiary gravels inland of Lagoon River near Sandy Cape on the West Coast. Hence it might be timely to re-review 19th century journals kept by geologists and prospectors (and contemporary issues of the Papers and Proceedings of the Royal Society of Tasmania) for documentary evidence of postglacial occupation sites in inland southwest Tasmania (cf. Jordan and Hill 2002).

The geographic extent of buttongrass moorland and the stability of its boundaries over time potentially can be tested by a combination of fossil pollen, carbonised particle and radiocarbon data from transects of sites located within, and across, the ecotones between forest and buttongrass moorland. Small hollows in outwash fans on the margins of the Arthur, Lake Pedder and Loddon Plains and at Cradle Mountain may be suitable sites (cf. Macphail 1984; Dodson et al. 1998). Whether management concerns justify research across the range of communities making up buttongrass moorland in southwest Tasmania is unknown, but modelling by King (2008) indicates that if boundaries are found to be geographically stable through time at a number of sites located away from Aboriginal trails, this would indicate at least $10 \%$ of the buttongrass moorland in southwest Tasmania had been burned on an annual basis. Ecological drift between the major vegetation types would indicate this 'fine mosaic' burning occurred on a smaller geographic scale or over a longer timeframe. Not surprisingly, it should be possible to use the same data to measure the impact of fires on the rate of accumulation of organic soils under buttongrass moorland (see Bowman 2008) and hence the potential value of buttongrass moorland for carbon capture and storage (cf. Hope et al. 2009). Insect remains potentially provide an alternative means of reconstructing past changes within buttongrass moorland (see Driessen 2008; Green 2008; Porch 2008), while the very small amount of organic matter now required to obtain reliable AMS dates means that independent age control can be obtained from the microfossil assemblages, even in sections that have been turbated by crayfish (Ombrastacoides, Spinastacoides) and other burrowing invertebrates (see Richardson and Doran 2008).

More speculatively, it may be possible to use fossil pollen data to reconstruct longerterm changes in soil $\mathrm{pH}$ and fire intensity, which can be correlated to particular climatic phases. For example, Brown et al. (1982) have shown that the distribution of woody and herb species in an 'alkaline pan-acidic peat' mosaic is influenced by soil $\mathrm{pH}$. It is tempting to speculate that changes in the (mostly low to trace) relative pollen abundance of these taxa may document longer-term trends in soil $\mathrm{pH}$ that can be related to fire if fossil pollen counts are sufficiently high. Similarly, Brown (1999) has concluded that plant community composition and structure, and the thickness of blanket peat cover are a function of fire intensity. Again (assuming appropriately high pollen counts), it is possible that changes in the relative pollen abundance of 'indicator' taxa are a natural archive of longer-term trends in fire intensity in southwest Tasmania.

\section{Conclusions}

Debate is likely to continue regarding the importance of indigenous fire activity relative to other environmental forcing factors at different periods within the Holocene, or in areas that are remote from Aboriginal habitation sites and trails through the southwest. Whether buttongrass moorland's past is a reliable guide to its future is equally debatable since the periods for which we have the most reliable palaeoecologic data were more uniformly wet than the $21^{\text {st }}$ century is predicted to be - a prediction given force by the increase in the number and extent of naturally ignited wildfires in the southwest in recent summers (J. SmedleyMarsden pers comm.). Frequent/extensive planned fires may be helpful in maintaining current vegetation boundaries (and biodiversity). However, 'mosaic' burning may also reduce the value of buttongrass moorland as an important resource for the capture and long-term storage of 
carbon if Bowman's (2008) prediction that the peat soils will become increasingly flammable proves to be correct. In a similar vein, warmer summer soil temperatures may assist the spread of the plant pathogen Phytophthora cinnamonii, which already infests 'tens of thousands of hectares' of buttongrass moorland (Rudman and Balmer 2008).

Accordingly, one task for those responsible for managing the southwest World Heritage Area, which encompasses the greater proportion of buttongrass moorland in Tasmania, will be to identify those natural attributes of buttongrass moorland that can be conserved under warmer/drier conditions. In this process, it is possible that the most important contribution that palaeoecology can make is to redefine humans as the creators as well as the destroyers and protectors of wilderness.

\section{Dedication and Acknowledgements}

The paper is dedicated jointly to Bill Jackson (University of Tasmania) and Geoff Hope (Australian National University), whose careers have been devoted unravelling the history of wet vegetation types across the Australasian region. Comments on an earlier draft by Greg Jordan (University of Tasmania) and an anonymous referee were, as always, of great assistance and much appreciated. Dr. Simon Haberle (Australian National University) kindly drafted Figure 2.

\section{References}

Anker, S.A., E.A. Colhoun, C.E. Barton, M. Peterson and M. Barbetti 2001. Holocene vegetation and paleoclimatic and palaeomagnetic history from Lake Johnston, Tasmania. Quaternary Research 56:264-274.

Birks, H.J.B. and H.H. Birks 1980. Quaternary Palaeoecology. Edward Arnold, London.

Bowman, D.M.J.S. 2008. Is global environmental change the end game for prehistoric vegetation legacies? The parallel cases of fire-maintained vegetation mosaics in southwest Tasmania and central Australia. Australasian Plant Conservation 16:6-8.

Bowman, D.M.J.S., A.R. Maclean and R.K. Crowden 1986. Vegetation-soil relations in the lowlands of south-west Tasmania. Austral Ecology 11:141-153.

Brown, M.J. 1999. Buttongrass moorlands. In J.B. Reid, R.S. Hill, M.J. Brown and M.J. Hovenden (eds) Vegetation of Tasmania, pp286-303. Canberra: Australia Biological Resources Study.

Brown, M.J., R.K. Crowden, and S.J. Jarman 1982. Vegetation of an alkaline pan-acidic heath mosaic in the Hardwood River Valley, Tasmania. Australian Journal of Ecology 7:3-12.

Caine, N. 1967. Carbon-14 dates from the Broad River Valley, Mt. Field National Park, Tasmania. Australian Journal of Science 31:119-120.

Colhoun, E.A. 1992. Late Glacial and Holocene vegetation history at Poet's Hill Lake, western Tasmania. Australian Geographer 23:11-23.

Colhoun, E.A. 1996. Application of Inversen's glacial-interglacial cycle to interpretation of the Last Glacial and Holocene vegetation of western Tasmania. Quaternary Science Reviews 15:557-580.

Colhoun, E.A. 2000. Vegetation and climate during the Last Interglacial-Glacial cycle in western Tasmania, Australia. Palaeogeography, Palaeoclimatology, Palaeoecology 155:195-209.

Colhoun, E.A. and A. Moon 1984. Estuarine sediments at the Bowen Bridge on the Derwent River, southeastern Tasmania. Search 15:224-226.

Colhoun, E.A., G. van de Geer, and W.G. Mook 1982. Stratigraphy, pollen analysis and paleoclimatic interpretation of Pulbeena Swamp, northwestern Tasmania. Quaternary Research 18:108-126. 
Colhoun, E.A. and G. van de Geer, 1986. Holocene to middle last glaciation vegetation history at Tullabardine Dam, western Tasmania. Proceedings of the Royal Society of London Series B, Biological Sciences 229:117-207.

Colhoun, E.A., G. van de Geer and S.J. Fitzsimmons 1991. Late Glacial and Holocene vegetation history at Governor Bog King Valley, western Tasmania. Journal of Quaternary Science 6:55-66.

Colhoun, E.A., G. van de Geer and S.J. Fitzsimmons 1992. Late Quaternary organic deposits at Smelter Creek and vegetation history of the middle King Valley, western Tasmania. Journal of Biogeography 19: 217-227.

Colhoun, E.A., J.S. Pola, and H. Heijnis 1999. Late Pleistocene vegetation and climate history of Lake Selina, western Tasmania. Quaternary International 57/58:5-23.

Conedera, M, W. Tinner, C. Neff, M. Meurer, A.F. Dickens and P. Krebs 2009. Reconstructing past fire regimes: methods, applications and relevance to fire management and conservation. Quaternary Science Reviews 28: 555-576.

Corbett, S. and J. Balmer 2008. Buttongrass moorland in Tasmania - what and where? Australasian Plant Conservation 16:3-5.

Cosgrove R. 1999. Forty-two degrees south: the archaeology of late Pleistocene Tasmania. Journal of World Prehistory 13:357-397.

Cosgrove, R., J. Allen, and B. Marshall, 1990. Palaeo-ecology and Pleistocene human occupation in south-central Tasmania. Antiquity 64:39-78.

Curtis, W.M. and D.I. Morris 1994. The Student's Flora of Tasmania, Part 4B. Angiospermae: Alismataceae to Burmanniaceae. Hobart: St David's Park Publishing.

Dodson, J.R. 2001. A vegetation and fire history in a subalpine woodland and rainforest region, Solomons Jewel Lake, Tasmania. The Holocene 11: 111-116.

Dodson, J.R., F.J.G. Mitchell, H. Bogeholz and N. Julian 1998. Dynamics of temperate rainforest from fine resolution pollen analysis, Upper Ringarooma River, northeastern Tasmania. Australian Journal of Ecology 23:550-561.1

Driessen, M. 2008. Buttongrass moorland fauna. Australasian Plant Conservation 16:20-22.

Fletcher, M.-S. and I. Thomas 2007a. Holocene vegetation and climate change from near Lake Pedder, south-west Tasmania, Australia. Journal of Biogeography 34:665-677.

Fletcher, M.-S. and I. Thomas 2007b. Modern pollen-vegetation relationships in western Tasmania, Australia. Review of Palaeobotany and Palynology 146: 146-168.

Green, D. 2008. The diversity of soil mites in Tasmanian buttongrass moorland in relation to vegetation age. Australasian Plant Conservation 16:24-28.

Harle, K.J., A.P. Kershaw, M.K. Macphail and M.G. Neyland 1993. Palaeoecological analysis of an isolated stand of Nothofagus cunninghamii (Hook.) Oerst in eastern Tasmania. Australian Journal of Ecology 18:161-170.

Harle, K.J., D.A. Hodgson and P. Tyler 1999. Palynological evidence for Holocene palaeoenvironments from the lower Gordon River Valley, in the World Heritage Area of south-west Tasmania. The Holocene 9:149-162.

Hill, R.S. 1982. Rainforest fire in western Tasmania. Australian Journal of Botany 30 583-589.

Hope, G.S. 1994. Quaternary vegetation. In R.S. Hill (ed) History of the Australian Vegetation: Cretaceous to Recent, pp368-389. Cambridge: Cambridge University Press.

Hope, G.S., R. Nanson and I.K. Flett 2009. Technical Report 19. The peat-forming mires of the Australian Capital Territory. Canberra: Territory and Municipal Services.

Iversen, J. 1958. The bearing of glacial and interglacial epochs on the formation and extinction of plant taxa. Uppsala Universiteit Arsskrift 6:210-215.

Jackson, W.D. 1968. Fire, air, water and earth - an elemental ecology of Tasmania. Proceedings of the Ecological Society of Australia 3:9-16. 
Jackson, W.D. 1977. Nutrient cycling in Tasmanian oligotrophic environments. In CSIRO (ed) Papers presented at a symposium organized jointly by W.A. Forests Department and CSIRO Division of Land resources Management, pp122-123. CSIRO, Como, W.A.

Jackson, W.D. 1999. The Tasmania legacy of man and fire. Papers and Proceedings of the Royal Society of Tasmania 133:1-14.

Jarman, S.J., G. Kantvilas, and M.J. Brown 1988. Buttongrass moorlands in Tasmania. Tasmanian Forest Research Council Research Report 2.

Jarman, S.J., G. Kantvilas, and M.J. Brown 1999. Floristic composition of cool temperate rainforest. In J.B. Reid, R.S. Hill, M.J. Brown and M.J. Hovenden (eds) Vegetation of Tasmania, pp145-159. Canberra: Australia Biological Resources Study.

Jordan, G.J. and R.S. Hill 2002. Cenozoic plant macrofossil sites of Tasmania. Papers and Proceedings of the Royal Society of Tasmania 136:127-139.

Kiernan, K., R. Jones, and D. Ranson 1983. New evidence from Fraser Cave for glacial age man in south-west Tasmania. Nature 301:28-32.

King, K.J. 2008. The relative importance of 'fine scale fuel mosaics' in reducing fire risk in southwest Tasmania. Australasian Plant Conservation 16:8-10.

Kirkpatrick, J.B. and M. Fowler 1998. Locating likely glacial forest refugia in Tasmania using palynological and ecological information to test alternative climatic models. Biological Conservation 85: 171-182.

Macphail, M.K. 1975a. History of the Vegetation in Southern Tasmania since the Late Pleistocene (ca. 13,000-0 BP). University of Tasmania: Ph.D. Thesis (2 Vols.).

Macphail, M.K. 1975b. Late Pleistocene environments in Tasmania. Search 6:295-300.

Macphail, M.K. 1979. Vegetation and climates in Southern Tasmania since the last glaciation. Quaternary Research 11:306-341.

Macphail, M.K. 1980. Natural regeneration processes in Tasmanian forests: a long-term perspective based on pollen analysis. Search 11:184-190.

Macphail, M.K. 1984. Small-scale dynamics in an early Holocene wet sclerophyll forest in Tasmania. New Phytologist 96:131-147.

Macphail, M.K. 1986. 'Over the top': pollen-based reconstructions of past alpine floras and vegetation in Tasmania. In B.A. Barlow (Editor) Flora and Fauna of Alpine Australasia: Ages and Origins, pp173-204. Melbourne: CSIRO.

Macphail, M.K. and R.R. Shepherd 1973. Plant communities at Lake Edgar, South West Tasmania. Tasmanian Naturalist 34:1-23.

Macphail, M.K. and W.D. Jackson, 1978. The late Pleistocene and Holocene history of the Midlands of Tasmania, Australia: Pollen evidence from Lake Tiberias. Papers and Proceedings of the Royal Society of Tasmania 90:287-300.

Macphail, M.K. and E.A. Colhoun 1985. Late glacial vegetation, climates and fire activity in southwest Tasmania. Search 16:43-45.

Macphail, M.K. and G.S. Hope 1985. Late Holocene mire development in montane southeastern Australia: a sensitive climatic indicator. Search 15:344-348.

Macphail, M.K., R.R. Shepherd, M.J. Brown and W.D. Jackson 1975. Norfolk Range Area Environmental Impact Statement. Devonport: Tasventure Environment Centre.

Macphail, M.K., M. Pemberton and G. Jacobson 1999. Peat mounds of southwest Tasmania: possible origins. Australian Journal of Earth Sciences 46:667-677.

Markgraf, V., J.P. Bradbury, and J.R. Busby 1986. Palaeoclimates in Tasmania during the last 13,000 years. Palaios 1:368-380.

Mount, A.B. 1979. Natural regeneration processes in Tasmanian forests. Search 10:180-186.

Patterson, W.A., K.J. Edwards and D.J. Maguire 1987. Microscopic charcoal as a fossil indicator of fire. Quaternary Science Reviews 6:2-23.

Porch, N. 2008. Invertebrates in landscape ecology. In D.B. Thomas (ed) Handbook of Landscape Archaeology, pp457-467. Walnut Creek: Left Coast Press. 
Read, J. 1999. Rainforest ecology. In J.B. Reid, R.S. Hill, M.J. Brown and M.J. Hovenden (eds) Vegetation of Tasmania, pp160-197. Canberra: Australia Biological Resources Study.

Richardson, A.M.M. and N.E. Doran 2008. The role of burrowing crayfish in Tasmanian sedgelands. Australasian Plant Conservation 16:22-24.

Rudman, T. and J. Balmer 2008. Death on the moor: the impact of Phytophthora cinnamonii on buttongrass moorland. Australasian Plant Conservation 16:29-31.

Thomas, I. 1993. Late Pleistocene environments and Aboriginal settlement patterns in Tasmania. Australian Archaeology 36:1-11.

Thomas, I. 1995. Where have all the forests gone? New pollen evidence from Melaleuca Inlet in south-western Tasmania. Monash University Publications in Geography 295-301.

Traverse, A. 1988. Paleopalynology. Boston: Unwin Hyman.

van de Geer, G., E.A. Colhoun, and W.G. Mook 1986. Stratigraphy, pollen analysis and paleoclimatic interpretation of Mowbray and Broadmeadow Swamps, north western Tasmania. Australian Geographer 17:121-133.

van de Geer, G., S.J. Fitzsimmons, and E.A. Colhoun 1989. Holocene to middle Last Glaciation vegetation history at Newall Creek, western Tasmania. New Phytologist 111:549-558.

van de Geer, G., S.J. Fitzsimmons, and E.A. Colhoun 1991. Holocene vegetation history from King River Railway Bridge, western Tasmania. Papers and Proceedings of the Royal Society of Tasmania 125:73-77.

Wells, P. and J. Hickey 1999. Wet sclerophyll, mix and swamp forest. In J.B. Reid, R.S. Hill, M.J. Brown and M.J. Hovenden (eds) Vegetation of Tasmania, pp224-243. Canberra: Australia Biological Resources Study.

Whitlock, C. and C.P.S. Larsen 2001. Charcoal as a fire proxy. In J.P. Smol, H.J.B. Birks and W.M. Last (eds) Tracking Environmental Change Using Lake Sediments, Volume 3 Terrestrial, Algal and Siliceous Indicators, pp75-97. Dordrecht: Kluwer Academic Publishers. 